Pamiętnik Literacki 2018, 3, s. 245-253

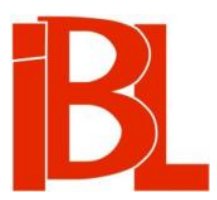

\title{
(Per)formacyjne projekty
}

Rec.: Konrad Niciński, W poszukiwaniu nowego czlowieka. Trzy projekty formacyjne w kulturze polskiej lat 19051930. Warszawa 2016.

Magdalena Rembowska-Płuciennik 
DOI: $10.18318 / \mathrm{pl} .2018 .3 .16$

MAGDALENA REMBOWSKA-PŁUCIENNIK Instytut Badań Literackich PAN, Warszawa

(PER)FORMACYJNE PROJEKTY

Ko n rad Niciński, W POSZUKIWANIU NOWEGO CZŁOWIEKA. TRZY PROJEKTY FORMACYJNE W KULTURZE POLSKIEJ LAT 1905-1930. (Recenzenci: Andrzej Mencwel, Lech Sokół). Warszawa 2016. Wydział Polonistyki Uniwersytetu Warszawskiego, ss. 192.

Projektowanie nowego człowieka jest nierzadko u swych podstaw skażone pychą lub nie zawsze uświadomionymi zapędami autorytarnymi, bez względu na to, czy wynika z umiłowania idei, czy ideologii. Motywacje do poszukiwań mogą być bardzo różne: najgroźniejsze 
to te polityczne (jak homo sovieticus), światopoglądowe, religijne, artystyczne - ich wspólne źródło bije w uzmysłowionym poczuciu nieprzystawalności profilu duchowego społeczeństwa do zmienionych warunków kulturowych. Chociaż postulaty odnowy wynikają z całkiem odmiennego nastawienia do zmian cywilizacyjnych (prezentuja nastroje katastroficzne, rewolucyjne czy też wzmacniają wiarę w ogólny postęp ludzkości), to łączy je chęć dostosowania jednostki i zbiorowości do wymagań nowej - obecnej lub przewidywanej - rzeczywistości. Książka Konrada Nicińskiego $W$ poszukiwaniu nowego człowieka. Trzy projekty formacyjne $w$ kulturze polskiej lat 1905-1930 umieszcza tytułowy wątek w szerokim kontekście europejskim, w którym zwłaszcza wpływy niemieckie bądź rosyjskie decydowały o specyfice polskich teorii na temat formacji duchowej współczesnych, a także przyszłych pokoleń. Niciński omówił trzy koncepcje wychowania ku przyszłości oraz samodoskonalenia, występujące w twórczości Tadeusza Micińskiego, Stanisława Ignacego Witkiewicza i Mieczysława Limanowskiego. Wybrany okres przyniósł jedne z najgwałtowniejszych wstrząsów w historii: rewolucję 1905, rewolucję październikową i pierwszą wojnę światową, zatem popularność poszukiwań formacyjnych wynikała zarówno $\mathrm{z}$ lęku przed chaosem, jak też $\mathrm{z}$ wiary w potrzebę i możliwość odnowy społeczeństwa po katastrofie lub w jej obliczu. Niciński przedstawił więc dyskusje, które nie były prowadzone na marginesach życia społeczno-kulturowego (wśród edukatorów, społeczników, pedagogów), ale toczyły się na skrzyżowaniu najrozmaitszych pól kulturowych i stanowiły wyrazisty, zróżnicowany i szeroki nurt w refleksji nad reformowaniem kultury europejskiej w czasach bardzo trudnych. Znamienne, że autor pisze wprost o „wielkiej bani z projektami formacyjnymi, która rozbije się pod koniec wieku XIX nad całą Europą" (s. 9), co nie tylko uzmysławia rangę tego typu piśmiennictwa, ale również ujawnia fakt, że temat ten nie stanowi często przywoływanego kontekstu w polskich badaniach nad literatura przełomu wieków. Jak przekonująco udowadnia Niciński - niesłusznie.

Dużą zaletą rozprawy jest dobór postaci, których idee uznał autor za reprezentatywne dla polskich projektów formacyjnych pierwszego trzydziestolecia XX wieku: Micińskiego, Witkiewicza oraz Limanowskiego. Niciński zastosował swoisty koncept kompozycyjno-problemowy, czyniąc przedmiotem omówienia spuściznę trzech jakże różnych (artystycznie i osobowościowo), a związanych ze sobą myślicieli, którzy stworzyli holistyczne wizje kultury, oparte na szczególnej misji duchowej teatru. „Miciński był "guru“ intelektualnym młodego Witkiewicza i mistrzem Limanowskiego. Ten ostatni z kolei był tutorem Stasia Witkiewicza, gdy ten był nastolatkiem” (s. 10). Splot biograficzny i pokrewieństwo zainteresowań wszystkich trzech bohaterów działalnością formacyjną pozwoliły autorowi rozprawy uczynić z ich wzajemnych relacji swoistą personalną soczewkę, skupiającą różne dziedziny twórczości, odmienne hierarchie wartości przypisywanych reformatorskim pomysłom, całkiem odrębne inspiracje dla zadania przeobrażenia życia indywidualnego i zbiorowego. Trwałym zwornikiem poglądów Micińskiego, Witkacego i Limanowskiego na możliwość uformowania nowego człowieka okazała się jednak przede wszystkim wiara w siłę oddziaływania teatru. Teatru pojętego jako medium i jako laboratorium duchowe, które wyraźnie profiluje artystycznie proces kształtowania nowego człowieka. Nicińskiego interesuje bowiem także laboratorium tekstowe jako środowisko powstawania projektów formacyjnych. Stąd widoczne nachylenie pracy ku refleksji nad ich literacką genezą i kształtem artystycznym, a nie nad zrealizowaniem pomysłów czy nad ich relacją z rzeczywista praktyką pedagogiczną wybranego okresu. W opinii autora zauważona „konstelacja biograficzna” umożliwia ponadto zastosowanie dialektycznego trybu w analizie rozwoju tych wizji: pisarstwo Micińskiego stanowiłoby tezę, do której antytezą miałaby być filozofia Witkacego. W tym układzie funkcję syntezy ich idei spełniają działania teatralno-literackie Limanowskiego, gdyż rzeczywiście nie tylko patronował on pracy wewnętrznej aktorów Reduty, ale i inspirował w tym zakresie największych ludzi teatru XX wieku (np. Jerzego Grotowskiego). Przenosząc to potrójne zestawienie na sferę historii, można by powiedzieć, że publicystyka Micińskiego prezentuje 
utopijną wersję projektów, twórczość Witkacego utrwala dystopijną de-formację, a pisarstwo krytyczne Limanowskiego nastawione jest na praktykowanie wyidealizowanej, nierzadko zaprawionej mistyką koncepcji pedagogicznej.

Rozdział poświęcony dziełom artystycznym i publicystyce Micińskiego zaczyna się od przypomnienia głównych antynomii, które wypełniały jego antropologię literacką i wyznaczały najważniejsze kierunki interpretacji. Pomiędzy biegunami przeciwstawnych pojęć (np. między figurami Lucyfera i Chrystusa, między znaczeniem pierwiastka ludzkiego a znaczeniem pierwiastka boskiego, między fascynacją ewolucją a gloryfikowaniem rewolucji - na przemian) wskazuje Niciński te powiązania myślowe, które w latach 1912-1913 ułożyły się w spójny projekt nowego człowieka. Autor rekonstruuje rozległe konteksty kulturowe poszukiwań europejskich, które miały wpływ na ukształtowanie się tej teorii, i są to wątki niezwykle interesujące.

Projekt Micińskiego został omówiony na tle bardzo szeroko zakrojonych koncepcji reformatorskich, obejmujących awangardowe prądy w muzyce, tańcu, teatrze, architekturze i myśli społecznej oraz społecznikowskiej. Ośrodkiem realizacji tych odnowicielskich koncepcji było „idealne” miasto-ogród Hellerau pod Dreznem. Budowane od podstaw dla robotników i inżynierów tamtejszych fabryk, miało tworzyć od razu środowisko holistycznie oddziałujące na rozwój mieszkańca i umożliwiające jego harmonijne współistnienie $z$ grupa ludzką i z przyrodą. Niciński fascynująco przedstawia, jak w pracy założycieli miasta realizowała się tęsknota do urzeczywistnienia utopii „miejsca szczęśliwego”: w projekcie przestrzeni miejskiej, w architekturze wnętrz i designie, w przyjętym systemie edukacji i promowaniu kultury, wreszcie w wizji stosunków społecznych. To tam znalazł swą siedzibę Instytut Dalcroze'a, czyli rewolucyjne studio nowoczesnego tańca i ruchu scenicznego, gdzie ćwiczenie cielesne miało służyć do wszechstronnego rozwoju fizyczno-duchowego, którego efektem ubocznym poniekąd była wartość estetyczna tańca. Autor pracy opisuje źródła fascynacji Micińskiego tym systemem edukacji, dotyczącej nie tylko tancerzy, i wskazuje w jego publicystyce $z$ lat 1912-1913 idee wiążące się z jego wyobraźnią antropologiczną. Jest to przede wszystkim wiara w głębokie, niemal mistyczne i rytualne znaczenie indywidualnie i zbiorowo uprawianej kultury fizycznej (z naciskiem na człon „kultura”), która ma przyczynić się do wszechstronnego duchowego odrodzenia człowieka. Stąd nawet relacja z igrzysk V Olimpiady w Sztokholmie jest poświęcona nie tyle sportowi wyczynowemu, ile prezentacji refleksji o modelowaniu człowieka przyszłości. W tym Miciński upatrywał szansy na zniesienie dualizmu ciała i ducha przenikającego myśl antropologiczna jego epoki ${ }^{1}$. Poszukiwał bowiem harmonii duchowego i cielesnego w różnych przejawach kultury tradycyjnej, formach misteryjnych czy pierwotnym ludowym poczuciu sakralnego porządku świata. Doświadczenie formacyjne wiązał $z$ odnowieniem idei antycznej paidei, misteryjności teatru antycznego, jak i z przeżyciem epifanii - ale epifanii wynikłej z ucieleśnionego doświadczenia (działania teatralnego, budującego hart i wolę ćwiczenia fizycznego).

Niciński dostrzega wiele niuansów ideologicznych w ewolucji myślenia autora Bazilissy Teofanu - przede wszystkim punkty niebezpiecznego zbliżania się reformatorów społecznych i projektantów nowego człowieka do działań czy koncepcji totalitarnych, w których niepostrzeżenie kształcenie jednostki i społeczeństwa przeinacza się w prze-kształcenie, hodowlę, wykuwanie człowieka przyszłości. Nieuchronnym kontekstem podskórnym tych rozlicznych programów są narodziny ideologii nacjonalistycznych i upolitycznienie/upaństwowienie edukacji bohatera przyszłych czasów. Na horyzoncie czai się przecież szaleństwo eugeniki ${ }^{2}$

Zob. M. S t a la, Pejzaż człowieka. Młodopolskie myśli i wyobrażenia o duszy, duchu i ciele. Kraków 1994.

2 O zasięgu tego ruchu w międzywojennej Europie traktują prace: „Blood and Homeland”: Eugenics and Racial Nationalism in Central and Southeast Europe, 1900-1940. Ed. M. Tu r d a, P. J. W e in- 
oraz inżynierii dusz w wydaniu bolszewickim i hitlerowskim, Leni Riefenstahl dokładnie za 20 lat będzie filmowała w Zwycięstwie wiary (1933), a potem w Olimpiadzie (1936) pięknie ukształtowanych i precyzyjnie współdziałających adeptów totalitarnej edukacji. Tych przykładów autor recenzowanej książki nie wprowadza (choć kontekst kulturowy nasuwa się z przemożną siła), ale wypunktowuje (choć można mieć wrażenie, że zbyt omownie i powściągliwie) drogi zbliżenia Micińskiego do nacjonalizmu oraz antysemityzmu. Kwestia niepodległościowa, która stopniowo zdominowała tematykę wypowiedzi publicystycznych autora Nietoty, rozpoczęła serię licznych nawiązań do romantycznego mesjanizmu i stopniowo wyparła na dalszy plan tematykę formacyjna spod znaku Hellerau. Wówczas projekt nowego człowieka uległ wypaczeniu w projekt Nowego Polaka, dając krytykom pisarza okazje do podobnych oskarżeń.

Podsumowując dyskusję na temat rzeczywistych poglądów politycznych Micińskiego, ich niekonsekwencji, rozchwiania między sprzecznymi postulatami, autor pracy stara się osłabić rangę zarzutów przez uwypuklenie estetyzującego czy kulturowego charakteru jego wizji nowego porządku świata i porządku wychowania. Uważam tę powściągliwość w jednoznacznej ocenie moralnej i intelektualnej projektów formacyjnych za zdecydowanie niewystarczająca. Pytanie o odpowiedzialność intelektualisty za owoce jego projektów, zwłaszcza w tak wrażliwej społecznie materii jak kształtowanie nowego człowieka, jest pytaniem o znaczeniu fundamentalnym. Tęsknota za posiadaniem siły sprawczej nad życiem indywidualnym i zbiorowym zawsze wkracza w sferę wolności i polityki, granice zaś między uszczęśliwianiem a przemocą mogą okazać się nader płynne. „Tekstowy” (pełen odniesień do filozofii i literatury) charakter projektów Micińskiego przy podejmowaniu przezeń wątków antyżydowskich czy nacjonalistycznych traci na znaczeniu. Tym bardziej że autor omawianej pracy nie uwydatnia zanadto tych zjawisk, które wyrastając np. z silnej fascynacji cielesnością i sprawnością fizyczną, przerodziły się w ciągu następnego 10-lecia w narzędzia zagłady. Kontekst eugeniki, bardzo prężnie rozwijającej się na terenach polskich od XIX wieku i po odzyskaniu niepodległości, reprezentowanej przez Polskie Towarzystwo Eugeniczne, prasę naukową ${ }^{3}$, w ogóle się w książce nie pojawia! A to też był projekt Nowego Człowieka, Nowego Narodu, Nowej Rasy...

Rozdział drugi rozprawy poświęcony jest rekonstrukcji myśli samokształceniowej w pismach Witkacego - działaniom formacyjnym sportretowanym jako podwójnie złowroga siła nacisku na jednostkę. Destrukcyjny wpływ na profil osobowościowy człowieka jemu współczesnego, jak i na człowieka przyszłości, mają bowiem nie tylko edukacyjne zapędy nauczycieli i instytucji szkolnictwa. Ponad nimi zachodzi proces de-formacji człowieka przez historię: niszczącą rewolucję, zmierzch cywilizacji, kres indywidualności. Niciński wprowadza do tradycyjnych badań nad historiozofią i biografią Witkacego (i do studiów nad nierozerwalnym ich splotem) ciekawy wątek zależności katastrofizmu antropologicznego od modelu eksperymentalnego kształcenia, jaki sam Witkiewicz za młodu odebrał. Ustalonych poglądów na temat filozofii Witkacego i jego wizji człowieka omawiana praca na pewno nie zmieni, naświetli wszakże pod nieco innym kątem dobrze przetarte ścieżki. Ten rozdział książki opiera się bowiem na odczytaniu teorii formacyjnych Witkiewicza-syna poprzez jego biografię, co samo w sobie nie pociaga jako działanie badawcze. Ponieważ jednak autor Narkotyków czynił sam siebie przedmiotem eksperymentów, jak i podmiotem eksperymentującym, wy-

dling. Budapest 2007. - Eugenika - biopolityka - państwo. Z historii europejskich ruchów eugenicznych $w$ pierwszej połowie XX wieku. Red. M. Gawin, K. Uzarczy k. Warszawa 2010. F. C a s s at a, Building New Man: Eugenics, Racial Science and Genetics in Twentieth-Century Italy. Transl. E. O' Lo u ghli n. Budapest 2011.

3 Zob. M. Gawi n, Rasa i nowoczesność. Historia polskiego ruchu eugenicznego 1880-1953. Warszawa 2003. 
korzystanie biografii pisarza zyskuje uzasadnienie. Niciński jako klucz do zrozumienia autoformacyjnych działań Witkacego przyjał jego wyostrzoną świadomość zagrożeń historycznych wyniesiona $z$ osobistych doświadczeń oraz prywatną niekonwencjonalną ścieżkę edukacyjną, jaką ustalił synowi Witkiewicz-ojciec. Obie te siły kształtujące człowieka - historię i system pedagogiczny - postrzegał Witkacy jako domeny opresji. Autor pracy pokazuje jednak, jak ukrytym motywem dramatów i powieści oraz tekstów autobiograficznych Witkiewicza stała się ambiwalentna fascynacja formowaniem drugiego człowieka: negatywnie ocenianym jako instytucjonalne narzędzie oraz $z$ upodobaniem wykorzystywanym jako własny środek oddziaływania na innych (także manipulowania nimi czy prowokacji względem nich). Witkacy ukazany jest zreszta $z$ obu perspektyw - jako buntownik przeciw modelowi kształcenia i formowania, jakiemu poddał go ojciec, oraz jako potencjalny mistrz wpływający na swoich uczniów. Potencjalny, bo - jak pisze Niciński - „gwiazdorska natura Witkiewicza potrzebowała raczej dworzan niż uczniów" (s. 122).

Ciekawe konteksty dla postawy Witkacego odnalazł Niciński również w innych projektach formacyjnych, które zrodziły się pod wpływem odziaływania Witkiewicza-ojca i były rozwijane w tym samym artystyczno-społecznikowskim środowisku Zakopanego początku XX wieku. Znamiennym przykładem jest utopia edukacyjna Antoniego Buszka, wdrażającego ideały wychowania przez sztukę ku etyce w ramach warsztatów rzemieślniczych dla dziewcząt. Do tego projektu Witkacy ustosunkowywał się niejednoznacznie - zarówno widząc jego skażenie idealizmem, jak i szanując tego projektu głęboko etyczne podstawy, oparte na systemie wychowania odebranym wspólnie pod okiem Witkiewicza starszego. To, co obydwu uczniom zostało jednak wpojone $z$ sukcesem - to przekonanie o immanentnej etycznej wartości prawdziwej sztuki, także sztuki czystej. Ta idea oparła się synowskiemu buntowi. Niciński wprowadza więc do swej analizy przeciwstawienie wychowania oraz edukacji - rzeczywistej działalności formacyjnej, ukierunkowanej przede wszystkim na pracę nad postawą wewnętrzną adepta, jego wrażliwością etyczną. Nie zawsze ta granica jest w omawianej książce jasno wytyczona. Jednakże to, co cenne w tych rozważaniach, to wyeksponowanie w konstrukcji utworów Witkacego elementów wyraźnie powiązanych z ową opozycją. W analizie poetyki dramatów i powieści udało się Nicińskiemu opisać i sfunkcjonalizować znaczenia układów personalnych zaprzeczających formowaniu, bo wdrażających wyniszczające osobowość uczonego metody tresowania, nakazywania i zakazywania. Takie znaczenie ma np. para postaci: ojciec-dziecko, element już dawno przez krytykę dostrzeżonego zdeformowanego obrazu rodziny, ale równie dobrze wytłumaczalny jako autonomiczny składnik antropologii literackiej Witkacego. Motyw ten służy obnażeniu opresyjnej natury edukacji, pedagogiki, okazuje się uzurpowaniem władzy demiurgicznej wręcz, choć nie potwierdzonej żadnym pozytywnym efektem. Analiza dramatów opiera się więc przede wszystkim na zgłębianiu konstrukcji bohaterów. Ponadto Niciński ciekawie przedstawia rozkład ról genderowych w tradycyjnym wychowaniu - gdzie przemoc ojcowska skorelowana jest z władzą, a zgubne oddziaływanie matki wiąże się z wynaturzoną i ośmieszoną „toksyczną” emocjonalnością. Na klęski duchowe bohaterów Witkacego można spojrzeć pod innym kątem, gdy dostrzeże się ich genezę w chybionej edukacji, jaką odebrali w rodzinie i w instytucjach społecznych. Okaleczenie duchowe, brak autorytetów, poczucie zagubienia w rozpadającym się świecie mają, jak się okazuje, dość wyraźne systemowe przyczyny w jałowej edukacji. Autor omawianej książki rekonstruuje biograficzne tło takich literackich poglądów Witkacego, ujawniając, które $z$ elementów jego antysystemowej edukacji domowej nie zostały poddane ostrej krytyce w twórczości artystycznej. Co ciekawe, rozbudzenie wrażliwości (estetycznej i metafizycznej) przypisuje Niciński właśnie efektom programu Stanisława Witkiewicza, a więc oddziaływaniu wymykającemu się pedagogice, a zbliżającemu do ćwiczenia formacyjnego. Podobnie systematyczność, rygor i samodyscyplina (także w ekscesach), oparte na umiłowaniu higieny fizycznej (coś, co u Witkacego może dziwić lub śmieszyć) okazują się pochodna idei wpajanych przez ojca. 
W rekonstrukcji poetyki dzieł Witkacego w świetle jego myśli formacyjnej Niciński niemal pominą jednak aspekt kulturowego tła jego twórczości. Po lekturze tej części można odnieść wrażenie, że antropologiczne przeczucia czy sądy pisarza tej miary zrodziły się zupełnie w oderwaniu od czysto artystycznych motywacji poszukiwania nowego człowieka i nowych form jego reprezentacji. Obserwujemy Witkacego jako zbuntowanego syna, całe życie borykającego się z traumą odrzucanej ojcowskiej edukacji. Jakiż to naiwnie okrojony wizerunek! Gwałtowny rozwój awangardy w sztukach wizualnych i w literaturze, obserwowany też przez Witkacego w gorącym okresie jego pobytu w Rosji, opierał się przecież na immanentnej potrzebie odnowienia środków formalnych dla wyrażenia zupełnie nowych problemów cywilizacyjnych i psychologicznych. Kontekstu samoświadomości artystycznej awangardzistów (zwłaszcza należących do młodszego niż Witkacy pokolenia, ale działających mniej więcej od połowy okresu, który interesuje Nicińskiego) w omawianej pracy nie znajdziemy ${ }^{4}$. Podobnie daremnie szukać dla idei Witkacego tła rozbudowanych, wielonurtowych powiązań między środowiskiem literatów a grupami awangardowych malarzy czy teoretyków sztuki, entuzjastów nowych mediów i nowych form artystycznych (fotografia, kolaż, film). Na darmo też szukać tu relacji artystycznych czy myślowych z Brunonem Schulzem, Deborą Vogel... Witkiewicz sportretowany przez Nicińskiego przynależy bardziej do grona pedagogów czy edukatorów krytycznie oceniających swą dziedzinę i poczynania jej reprezentantów, a przez przypadek ten spór wewnętrzny toczy się w dramatach, powieściach czy krytyce artystycznej autora Pożegnania jesieni. Jego działalność artystyczna zaś, niepostrzeżenie dla Nicińskiego, ale dość wyraźnie dla czytelnika, nabiera obrachunkowego charakteru, myślowo ciąży bardziej ku doświadczonej przeszłości niż twórczej aktualności czy innowacyjności. Nawet jeśli Nienasycenie zostaje nazwane „antyutopią futurologiczna” (s. 118), to Witkacy przypomina Joachima von Bertranda z Lunatyków Hermanna Brocha, skarżącego się, iż „poczucie życia $z$ reguły o jakieś pół wieku albo i cały wiek pozostaje w tyle za życiem rzeczywistym"5.

Ostatni bohater książki Nicińskiego to Mieczysław Limanowski - tutor młodego Witkiewicza i zarazem człowiek będący pod przemożnym wpływem osobowości i myśli Micińskiego. Tym samym książka realizuje zgrabny zamysł koncepcyjno-kompozycyjny, omawiając trzech ludzi pióra związanych $\mathrm{z}$ teatrem, zafascynowanych doświadczeniem formacyjnym i kształtujących swe koncepcje w bezpośredniej wzajemnej relacji. Działalność teatralna Limanowskiego (zarówno artykuły teoretyczne, krytyka teatralna, jaki i praca z zespołem aktorskim nad przygotowaniem i realizacją spektaklu) stanowi w omawianej rozprawie swoista kulminację - przedstawia bowiem projekt wdrożony w życie, formujący rzeczywiście społeczność studia teatralnego Reduta. Ze względu na rangę tej instytucji (edukacyjną, artystyczną, środowiskową) i z uwagi na ekscentryczność Limanowskiego, skojarzoną z jego dużą aktywnością, ta część pracy prezentuje się jako pasjonująca opowieść o nietuzinkowym, acz niedocenianym przewodniku duchowym. Jak podsumowuje paradoksy tej postaci Niciński: „Sens analiz Limanowskiego docierał do aktorów niejako przy okazji, ich uwagę skupiała raczej dziwność ich przekazywania niż ich charakter. Tak więc "szalony szaman", który mówi "stań się" - i rola się staje. Nie nauczyciel, nie ktoś, kto formuje. Tak postrzegany był raczej Osterwa. Tymczasem najczęściej było raczej na odwrót” (s. 157).

Atutem zaprezentowanej tu historii Limanowskiego jest usytuowanie jego koncepcji formacyjnej wobec wizji artystycznej i praktyki twórczej najważniejszych ludzi teatru polskiego początku XX wieku, zwłaszcza po odzyskaniu niepodległości: wobec Juliusza Osterwy, Leona Schillera, w sporze z krytyką teatralną Antoniego Słonimskiego. Badacz odtwarza 
także, w jaki sposób Limanowski spożytkował i skodyfikował wpływy Micińskiego - wcielając w życie wzorce $z$ Hellerau oraz przekonania autora Nietoty co do parareligijnych, misteryjnych, rytualno-katartycznych źródeł i funkcji odradzającego się teatru narodowego. Drobiazgowo rekonstruuje recepcje poglądów Micińskiego przez jego akolitę (na poziomie historii absorpcji pojęć, poprzez działalność na rzecz upowszechnienia zasad pedagogiki Dalcroze'owskiej, poprzez propagowanie idei wspólnotowego przeżycia obrzędu, jakim miał być spektakl). Wskazuje także motywy i sposoby przekroczenia dziedzictwa nauczyciela, przede wszystkim w kierunku rzeczywistego doświadczenia mistycznego, w kierunku jednostkowej epifanii cementującej wspólnotę. Tym samym odsłania ścieżki, które prowadziły do najbardziej fascynujących powojennych zjawisk w teatrze polskim: Laboratorium, Gardzienic, Cricot II.

Niciński opisuje indywidualną pracę Limanowskiego $\mathrm{z}$ aktorami studia oraz wdrażane przez niego praktyki wspólnotowe, uwypuklając napięcia pomiędzy ideałami formatora, celami realizatora przedstawienia i ambicjami lub aspiracjami profesjonalnymi aktora. Z nieukrywaną sympatią staje po stronie swojego bohatera, oddając mu to, czego nie otrzymał on od swoich współczesnych, zrażonych do ekscentryka. Tłem dla opowieści o programie rozwoju indywidualnego i wspólnotowego, jaki popularyzował Limanowski, jest historia narodzin i przenikania do Polski wiedzy o metodzie Konstantina Stanisławskiego i najnowszych kierunkach w pracy $\mathrm{z}$ aktorem, które zrodziły się wówczas w Rosji. To drugi ukazany w książce kierunek inspiracji decydujący o teatrologicznym ruchu formacyjnym w Polsce; geograficzne usytuowanie otwierało symbolicznie i realnie Polskę na wpływy Hellerau oraz Moskwy, jako siedziby Moskiewskiego Teatru Artystycznego. Podskórny nurt wywodu Nicińskiego stanowi historia wymiany doświadczeń i wiedzy, transfer idei kulturowych w naszej części Europy, która u początku wieku kipiała od nowatorskich koncepcji artystycznych i naukowych, wstępnych pomysłów, eksperymentów myślowych. Zbadanie dziejów rozmaitych przesunięć semantycznych, odkształceń idei zrodzonych w bliskim nam środowisku intelektualnym Europy Wschodniej, spowodowane ich wybiórczą, nierzadko dość powierzchowną recepcją na Zachodzie, to nadal projekt nie zakończony a fascynujący. Cennych uwag na ten temat (choć niejako na marginesie głównych zainteresowań badacza) także dostarcza prezentowana rozprawa.

W zakończeniu Niciński ujawnia swój krytyczny stosunek do utożsamiania idei nowego człowieka $z$ hasłami awangardy; odmawia słuszności takim poglądom i dodatkowo tłumaczy przesłanki niemal zupełnego pominięcia tego kontekstu w swoich rozważaniach. Uzasadnia tę kontrowersyjną decyzję niskim nasyceniem awangardowych projektów elementem formacyjnym, który dla niego stanowi główny przedmiot zainteresowania. Czyni to jednak w bardzo ogólnikowy sposób i na tyle późno, by nawet w przychylnym tej interpretacji czytelniku wywołać wrażenie pośpiesznego tłumaczenia się z braku głębszej refleksji nad tym elementem. Jeśli nowy człowiek niejedno miał oblicze ( $\mathrm{z}$ czym, oczywiście, można się zgodzić), to z pewnością nie należy mu nakładać jednej maski. Autor stwierdza:

„Jest on [tj. Nowy Człowiek awangardy] przede wszystkim faktem artystycznym. O możliwych kształtach nowej sztuki dla nowego człowieka możemy rozprawiać nieskończenie; trudno jednak określić, czym miałaby być ontologia Nowego Człowieka awangardy, czy jaka myśl antropologiczna mu towarzyszy. Pod tym względem wizja awangardowa jest niesamodzielna, korzysta z rozmaitości istniejących systemów" (s. 178).

Zbyt łatwo przychodzi autorowi to uogólnienie, gdyż całkowicie pominął ważny aspekt antropologii literackiej: możliwość kodowania znaczeń antropologicznych i etycznych w samej sferze formy. Odpowiedzi na pytania, „co to znaczy być jednostką ludzką w danym momencie historii” lub ,jaki jest nowy człowiek”, można udzielić także na podstawie analizy praktyk artystycznych, niekoniecznie tylko biorąc pod uwagę wypowiedzi okołoliterackie, metaliterackie czy światopogląd konkretnego pisarza. Wówczas sam tekst przekształca się w swoiste laboratorium pracy twórczej. To w tekście zachodzi proces poznania literackiego 
i w nim upatrywać można ośrodka „awangardowego światopoglądu”, w którego istnienie Niciński powątpiewa. Deklarując na początku rozprawy zainteresowanie tekstową naturą omawianych projektów (która ma wytłumaczyć brak części dotyczącej pedagogiki Janusza Korczaka), neguje zarazem możliwość ich literackiej proweniencji. Skupia się bowiem na programach formacyjnych literaturze „zadanych”, traktujących ją jako materiał ilustracyjny dla uprzednio powziętych idei. Dlatego pewnie pomija zaistnienie bytu faktycznie wcześniej rzadko zauważalnego - realnego czytelnika współuczestniczącego w komunikacji artystycznej. Tego czytelnika awangardowi pisarze starali się zaktywizować i włączyć nie tylko w sferę wewnętrznej budowy dzieła (tradycja pozwala na to dzięki licznym konwencjonalnym środkom: apostrofy, monolog kierowany do fikcyjnego lub realnego odbiorcy), ale i w proces operowania tekstem. Laboratorium tekstowe uruchamia interakcję, a sam tekst literacki uwzględnia sytuację rzeczywistej lektury jako podstawowy warunek swego zaistnienia.

„Hallo! Hallo!

Czy mnie słyszycie? Nie? Nie szkodzi. I tak się zrozumiemy! A teraz zaczynamy!

Ale w jakim momencie życia Perdity rozpocząć tę powieść? Powieść? Powieść gdzie? Doką??"6

Szczególnie ciekawie rysują się te eksperymenty literackie, jeśli uzmysłowimy sobie, iż dzisiejsza literatura, np. w postaci hiperpowieści, realizuje podobne cele w multimedialnym środowisku internetu. W licznych działaniach formalnych przejawiał się ten sam impuls wręcz edukacyjny: przygotować odbiorcę do radykalnego odświeżenia sposobów percepcji sztuki, uczynić komplikację formalną ekwiwalentem doświadczenia współczesności - niejednoznacznej, heterogenicznej, przekształcającej środowisko medialne i przestrzeń społeczną. Czytelnik ówczesny w znacznie większym stopniu myślał wizualnie, deskrypcja przedmiotowa ustępować więc musiała wielokrotnie miejsca zgeometryzowanym wizjom kina abstrakcyjnego (a literaci chętnie podejmowali się współpracy z kinem ${ }^{7}$ ), co zmieniało zasady konstrukcji opisu i postać gatunkową powieści. Odbiorca np. Psychoanalityka w podró$\dot{z ̇ y}$ (1929) mógł wybrać odpowiadające mu zakończenie, pisząc na... paryski adres Brzękowskiego. Brzękowski zresztą domagał się „sitwy z czytelnikiem” (w powieści 24 kochanków Perdity Loost, powstałej w roku $1939^{8}$ ) jako modelu komunikacji mocno skracającej dystans. Taki projekt literackiego nowego człowieka nie opiera się zbyt mocno na założeniach etycznych, które interesują Nicińskiego - nie służył stworzeniu człowieka idealnego, ale zaledwie zaaklimatyzowanego w nowych procesach kulturowych. Nie był narażony zatem na niebezpieczeństwo rozziewu między pięknem teorii a rozczarowaniem wynikłym z praktyki, czemu do pewnego stopnia podległy wszystkie stricte formacyjne teorie zaprezentowane w rozprawie W poszukiwaniu nowego człowieka.

Abstract

MAGDALENA REMBOWSKA-PŁUCIENNIK Institute of Literary Research of the Polish Academy of Sciences, Warsaw

\section{(PER)FORMATIVE PROJECTS}

The review presents the methodological assumptions and the scope of problems of Konrad Niciński's work $W$ poszukiwaniu nowego człowieka. Trzy projekty formacyjne $w$ kulturze polskiej lat 1905-1930

6 J. Brzę kow s ki, 24 kochanków Perdity Loost. Londyn 1961, s. 8.

7 Zob. A. Wój tow i cz, „Kino - choroba dnia dzisiejszego”. Powieść awangardowa i film. W zb.: Komunikowanie i komunikacja w Dwudziestoleciu międzywojennym. Red. K. Stępnik, M. Rajew s ki. Lublin 2010.

$8 \quad$ P. Majerski, Boczny tor awangardowego eksperymentu... (O powieściach J. Brzękowskiego). „Ruch Literacki” 1999, nr 6. 
(In Search of a New Man. Three Formative Projects of Polish Culture 1905-1930). The subject is not a frequently recalled research context for Polish literature of the turn of the $19^{\text {th }}$ and $20^{\text {th }} \mathrm{c}$. which, as Niciński convincingly proves, is unjustified. The value of the book also lies in the description of the problem in question as based on the examples of eminent and charismatic authors of the beginning of the $20^{\text {th }}$ century, namely Witkacy, Tadeusz Miciński, and Mieczysław Limanowski. 